\title{
Geothermal Investigations and Hydrocarbon Potentialities of the Northwestern Desert, Egypt
}

\author{
Hassan M. Hosney \\ Department of Geophysics, Faculty of Science, \\ Cairo University, Cairo, Egypt
}

Received: 13/12/2004 Revised: 14/6/2005 Accepted: 24/5/2005

Abstract. 269 bottom hole temperature measurements at 124 wells distributed in the Northwestern Desert and the Nile Delta of Egypt were used for obtaining the geothermal gradient values at each well. Heat flow values over the studied area were found to range between $43-110 \mathrm{Wm}^{-2}$. There is a regional decrease in geothermal gradient values northward, which was interpreted as due to thinning of the continental crust toward the Mediterranean Sea. This trend apparently correlates with decrease in crustal thickness from about $33 \mathrm{~km}$ at the southern part of the studied area, to $24 \mathrm{~km}$ beneath the Mediterranean coast. These geothermal gradient values were used for constructing the upper and lower limit of the expected hydrocarbon window in the area. The thickness of the hydrocarbon windows reaches up to $3 \mathrm{~km}$. Maps representing the depth of these isotherms and the isopach map for the hydrocarbon window were correlated with known sedimentary basins in the Paleozoic. Fairly good correlation was found especially for thickness of hydrocarbon window values $>2 \mathrm{~km}$ with the distribution of these basins. Geothermal trend analysis reveals the presence of the following main trends: $\mathrm{N} 45^{\circ}-65^{\circ} \mathrm{E}$ (Syrian arc, Pelusium and Siwa-Alexandria), N25 ${ }^{\circ} \mathrm{W}$ (Red Sea and Gulf of Suez) and $\mathrm{N} 80^{\circ} \mathrm{E}$ (Tethyan Sea). These lineaments appear to be caused primarily by basement structures and overlying sediments. They affect the hydrocarbon oil window of the area. Parts of the study area which are not explored yet but show thick hydrocarbon window (2.5-3 km) are considered as target areas for future exploration programs.

Keywords: Geothermal Gradient, Heat Flow, Hydrocarbon Window. 


\section{Introduction}

The eastern Mediterranean region is characterized by low heat flow 30-45 $\mathrm{mWm}^{-2}$ (Morgan et al., 1977 and Čermak et al., 1977). The average of the marine heat flow measurement in the Levantine sea is $25.7 \pm 8.4 \mathrm{mWm}^{-2}$ and on Cryprus is $28.0 \pm 8.0 \mathrm{mWm}^{-2}$. The estimated values of heat flow in northern Egypt range from $38.3 \pm 7.0$ to $49.4 \pm 9.3 \mathrm{mWm}^{-2}$, apparently with no consistant trend (Eckstein, 1978). In the Nile Delta heat flow values range between 39 and $56 \mathrm{mWm}^{-2}$ (Riad et al., 1989). The plate margin to the north of Egypt appears to be too distant to result in any geothermal anomalies in northern Egypt. The low heat flow of the eastern Mediterranean Sea extends at least as far south as $29^{\circ} \mathrm{N}$ (Morgan et al., 1977 and Čermak et al., 1977).

Previous studies of heat flow and geothermal regime in Egypt (Issar et al., 1971; Morgan et al., 1980; 1983; 1985; Swanberg et al., 1983; Boulus, 1990; Zaghloul et al., 1995; Hosney and Dahroug 1999; Hosney and Morgan, 2000; Hosney 2002) related the geothermal features with the tectonic evolution of the area. Hosney and Morgan (2000) found a strong correlation among geothermal anomaly and the basement surface in the northern Gulf of Suez suggesting shallower origin of these anomalies. Many of these anomalies are caused by thermal refraction associated with thermal conductivity contrast between basement and sedimentary rocks. Groundwater thermal convection is required in some localities to explain the high gradients. Local variations in geothermal gradient in northern Egypt are thought to be primarily due to thermal conductively variations.

\section{Bottom Hole Temperature Data Correction and Geothermal Gradient Determination}

Maximum temperatures are routinely recorded in well-logging runs in oil wells. As the geothermal gradient is generally positive with increasing depth, these maximum temperatures are usually assumed to represent the bottom-hole temperature (BHT) at the time of logging. This temperature does not represent the true formation temperature because the circulation of drilling fluid during and after drilling causes a thermal transient in the well where the drilling fluid and the formation temperatures are unequal. Numerous methods have been suggested to correct the measured BHT values for the drilling fluid disturbance (e.g., Horner, 1951; Lachenbruch and Brewer, 1959; Dowdle and Cobb, 1975; Middleton, 1979; Luheshi, 1983; Ribeiro and Hamza, 1986; Shen and Beck, 1986). These methods have been reviewed by Beck and Balling (1988). The "Horner plot" method of Horner, 1951 was widely used for making the correction. This method is an empirical approximation based upon the following equation: 


$$
\mathrm{T}\left(\mathrm{t}_{\mathrm{s}}\right)=\mathrm{VRT}+(\mathrm{Q} /(4 \pi \mathrm{K})) \ln \left(1+\mathrm{t}_{\mathrm{c}} / \mathrm{t}_{\mathrm{s}}\right)
$$

Where $T\left(t_{s}\right)$ is temperature at time $t_{s}$, VRT is the formation (virgin rock) temperature, Q is the heat supplied (or extracted) by the drilling fluid per unit length per unit time, $\mathrm{K}$ is thermal conductivity, $\mathrm{t}_{\mathrm{s}}$, is the time since circulation ceased, and $t_{c}$, is the time that circulation was maintained at the measurement depth. Although this technique has deficiencies (Beck and Balling, 1988), yet it is commonly used because it requires only knowledge of $t_{c}$ and $T$ for two different values of $t_{\mathrm{s}}$. VRT may be obtained as the temperature intercept of a linear plot of $T\left(t_{s}\right)$ versus $\log 10\left(t_{s} / t_{c}+1\right)$ (Hosney and Morgan, 2000).

Figure 1 shows the location of oil wells used in this study (Fig. 1a) along with the generalized litho-stratigraphic column of the northern Western Desert (Fig. 1b). Geothermal gradients were calculated (equation 2) using the corrected BHT data for each individual well by assuming a mean surface temperature of $26^{\circ} \mathrm{C}$ (Morgan et al., 1977) and a geothermal gradient map was plotted (Fig. 2a).

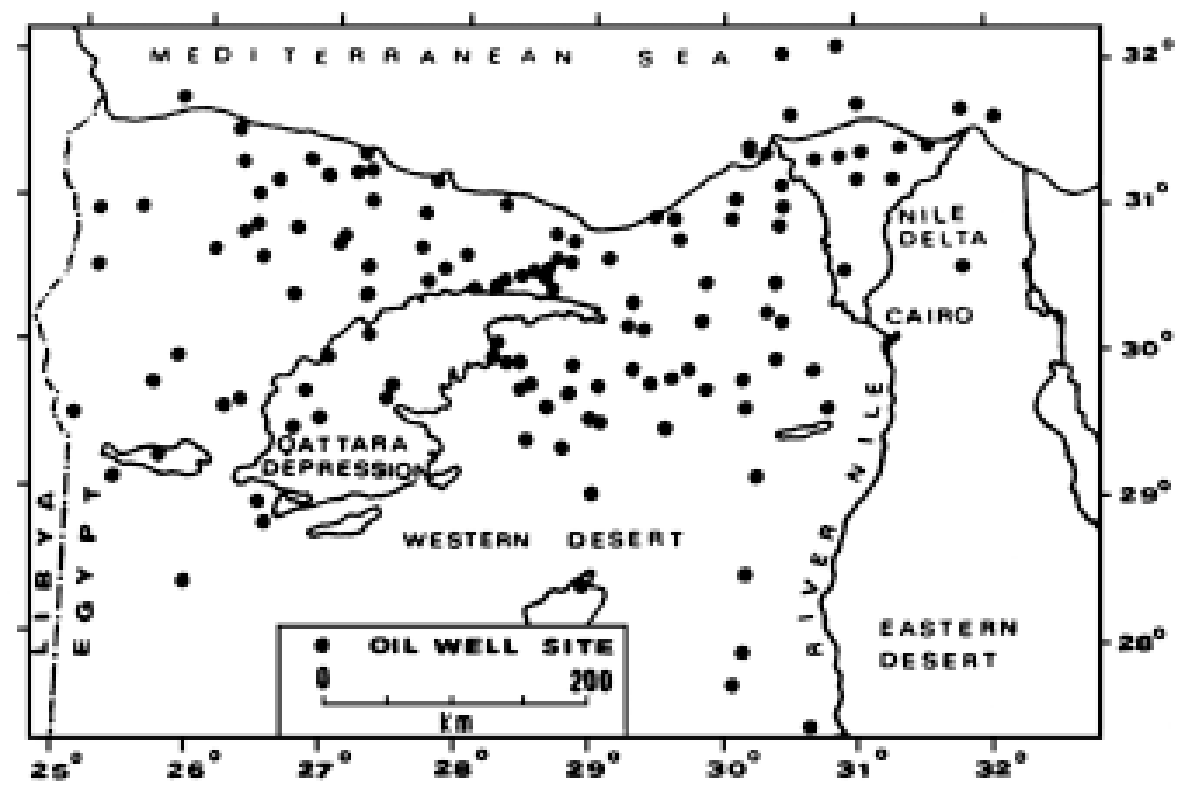

FIG. 1(a). Location map of the oil wells in this study.

$$
\mathrm{G}=\mathrm{dT} / \mathrm{dZ}=\left(\mathrm{T}_{\mathrm{Z}}-\mathrm{T}_{0}\right) / \mathrm{Z}
$$

Where $\mathrm{G}$ is the geothermal gradient, $\mathrm{T}_{\mathrm{Z}}$ temperature at depth $\mathrm{Z}$ and $\mathrm{T}_{0}$ is surface temperature. The corrected geothermal gradient values are found in the range between $19.8^{\circ} \mathrm{C} \mathrm{km}^{-1}$ and $51^{\circ} \mathrm{C} \mathrm{km}^{-1}$. The highest gradient is located in the southern middle part south of latitude $29^{\circ} \mathrm{N}$. Considering thermal conductivity values (Table 1) for the rocks forming the stratigraphic section in northern 


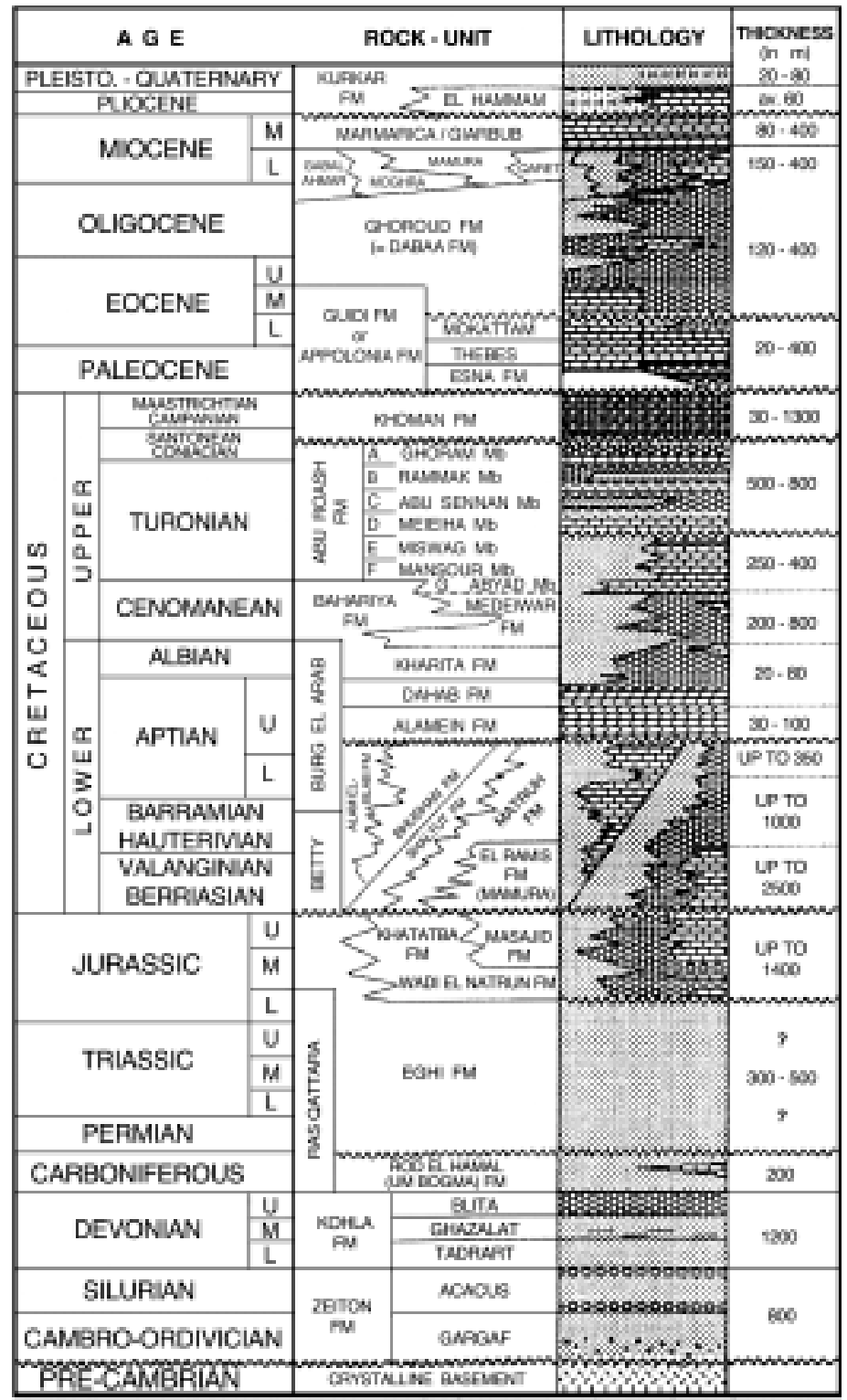

FIG. 1(b). Generalized litho-stratigraphic column of the northern Western Desert of Egypt (Schlumberger, 1984 and 1995). 

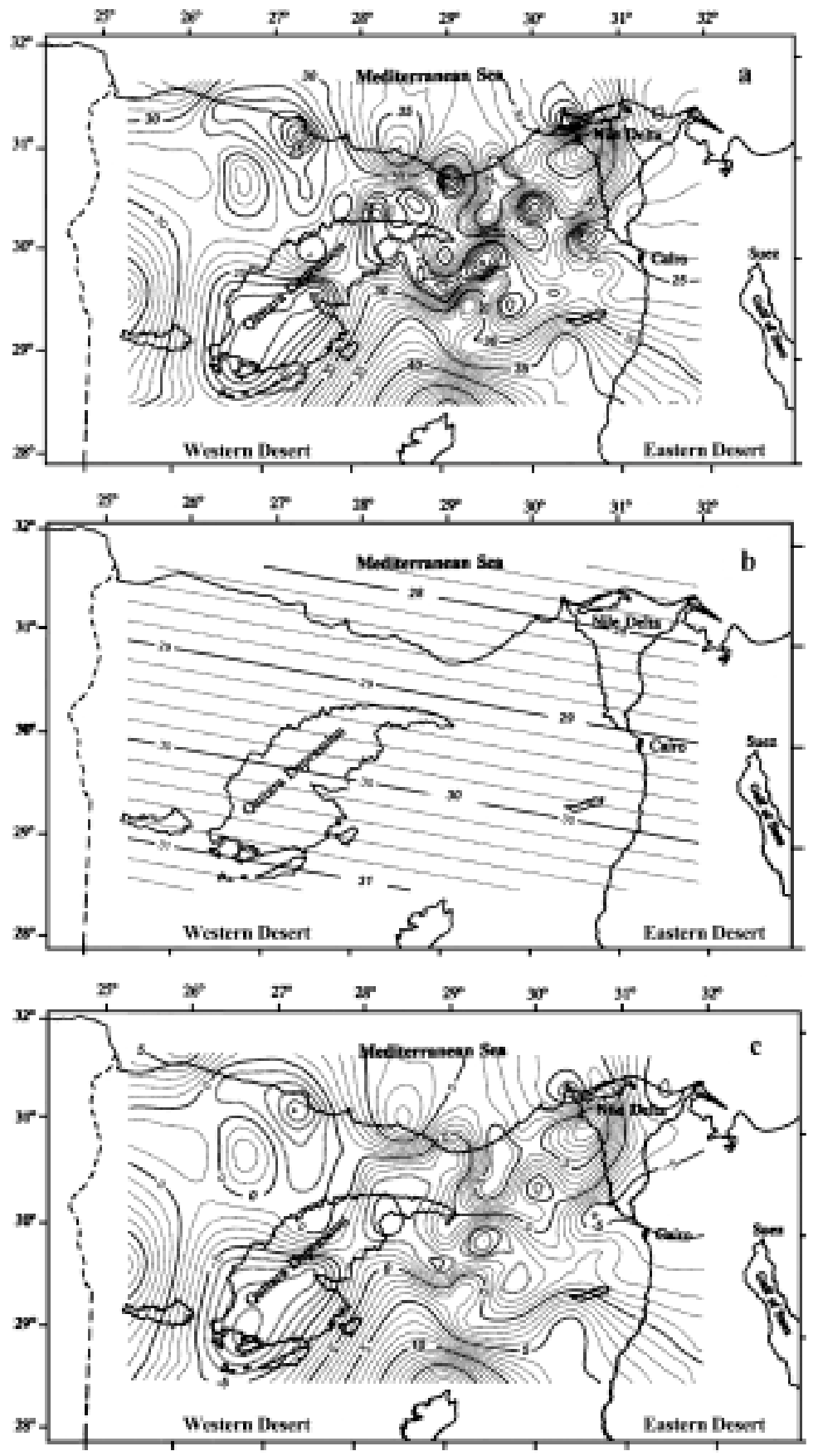

FIG. 2(a). Geothermal gradient of the northwestern desert (contour interval $1^{\circ} \mathrm{C} \mathrm{km}^{-1}$ ).

(b). Regional component of geothermal gradient (c. i. $1.0^{\circ} \mathrm{C} \mathrm{km}^{-1}$ ).

(c). Residual component of geothermal gradient (c. i. $0.2^{\circ} \mathrm{C} \mathrm{km}^{-1}$ ). 
Egypt to range between $2-2.3 \mathrm{w} / \mathrm{m}^{\circ} \mathrm{C}$ (Morgan et al., 1983), heat flow values over the studied area were calculated using equation 3 and were found to range between $43-110 \mathrm{mWm}^{-2}$.

$$
\mathrm{q}=\mathrm{k}(\mathrm{dT} / \mathrm{dZ})
$$

TABLE 1. Northern Egypt generalized stratigraphic column and thermal conductivities (after Morgan et al., 1983).

\begin{tabular}{|c|c|c|c|}
\hline Age formation & Aver. thickness (m) & Basic rock type & $\mathrm{k}(\mathrm{W} / \mathrm{m} / \mathrm{K})$ \\
\hline Pliocene & 58 & Calcarenite and Sdy, Lst & 2.1 \\
\hline $\begin{array}{l}\text { M. Miocene } \\
\text { Marmarica }\end{array}$ & 183 & Limestone & 2.2 \\
\hline L. Miocene Moghra & 213 & Sand and gravel & 2.1 \\
\hline $\begin{array}{l}\text { Oligocene } \\
\quad+\text { U. Eocene } \\
\text { Dabaa }\end{array}$ & 503 & Shale & 1.5 \\
\hline $\begin{array}{l}\text { M. + L. Eocene } \\
\text { Apollonia }\end{array}$ & 122 & Limestone & 2.2 \\
\hline $\begin{array}{l}\text { U. Cretaceous } \\
\text { Khoman }\end{array}$ & 244 & Chalk & 1.8 \\
\hline $\begin{array}{l}\text { U. Cretaceous } \\
\text { Abu Roash }\end{array}$ & 457 & Limestone and shale & 2.0 \\
\hline $\begin{array}{l}\text { U.-L. Cretaceous } \\
\text { Bahariya } \\
\text { Kharita }\end{array}$ & 488 & Sandstone with shale & 2.6 \\
\hline $\begin{array}{l}\text { L. Cretaceous } \\
\text { Alamein }\end{array}$ & 219 & Dol., Sdy., Dol., Lst. & 3.8 \\
\hline $\begin{array}{l}\text { L. Cretaceous } \\
\text { Alam el-Buib/ } \\
\text { Matruh Shale } \\
\text { Sidi Barrani }\end{array}$ & 1219 & Sandstone and shale & 2.6 \\
\hline $\begin{array}{l}\text { U. Jurassic } \\
\text { Masajid }\end{array}$ & 305 & Limestone and shale & 2.0 \\
\hline $\begin{array}{l}\text { M. Jurassic } \\
\text { Khatatba }\end{array}$ & 610 & Shale & 1.8 \\
\hline $\begin{array}{l}\text { L. Jurassic } \\
\text { Wadi Natrun }\end{array}$ & 207 & Limestone & 3.4 \\
\hline Permian-Cambrian & 1829 & Shale and limestone & 2.6 \\
\hline Precambrian & & Basement rocks & 2.9 \\
\hline
\end{tabular}

For one-dimensional temperature variation, the heat flow q depends on thermal gradient $\mathrm{dT} / \mathrm{dZ}$ and thermal conductivity $\mathrm{k}$.

In order to determine the regional variation in the geothermal gradient over the studied area, the regional component was calculated using surface fitting techniques. Figure $2 b$ shows the first order polynomial surface fitting of the 
geothermal gradient data. There is a regional decrease northward towards the Mediterranean Sea. The residual component is illustrated in Fig. 2c. To explain this trend of regional variation, the Bouguer anomaly map (Kamel, 1990) (Fig. 3a) was separated into regional (Fig. 3b) and residual (Fig. 3c) components. The regional gravity map of the first order polynomial (Fig. 3b) shows increase in gravity northward, which could be associated with deep crustal structures. 2D gravity modeling along 2 profiles (AA' and BB') was calculated (Fig. $4 \mathrm{a}$ and b). The densities used in the gravity modeling were determined using Nafe-Drake relation 1963, according to the seismic velocities determined from the CairoBaharia Deep Seismic Sounding, where Pg and Pn were found to be 6 and 8 $\mathrm{km} / \mathrm{sec}$ respectively and basement depth ranges from 1.9-3.1 km, whereas Con$\mathrm{rad}$ and Moho discontinuities are 22 and $34 \mathrm{~km}$ respectively (Makris et al., 1982; Marzouk, 1988; Hosney 2002). The densities of the upper crust, lower crust and upper mantle were found to be $2.67,2.9$ and $3.3 \mathrm{~g} / \mathrm{cm}^{3}$ respectively.

The structure models reveal that the depth of the Moho discontinuity varies between $33 \mathrm{~km}$ at the south to $24 \mathrm{~km}$ at the Mediterranean coast. The gravity anomalies are mainly due to basement structures. The regional increase in gravity may be explained by northward thinning of the continental crust. Since the continental crust contains a relatively high density of radioactive isotopes, the decrease in the thickness of the continental crust may cause regional decrease in the geothermal gradient and heat flow. Similar cause was given by Eckstein, 1978 and 1979 to explain the west-east increase trend of heat flow from Egypt towards Israel as being due to an increase in crustal thickness from about $23 \mathrm{~km}$ at the north-west base of the Nile Delta cone, to close to $40 \mathrm{~km}$ beneath Israel.

\section{Hydrocarbon Potentials of the Northwestern Desert of Egypt in Relation to Geothermal Regime}

Average shales contain approximately 1 percent organic matter (Hunt, 1972; Barker, 1982). About 90 per cent of this is the high molecular weight, insoluble, polymeric material called kerogen and the rest is solvent soluble and is the bitumen fraction (Fig. 5). The bitumen changes in amount and composition in response to changing in biological and physical conditions (Barker, 1982).

Since kerogen accounts for over ninety per cent of the organic matter in shales, small changes in its composition can produce large changes in the nature of the lower molecular weight and solvent extractable bitumens that are generated from it. The trend of increasing carbon content in the kerogen with progressive burial is balanced by increasing hydrogen content in the bitumens, and they become more paraffinic and lower in molecular weight as thermal maturation proceeds. The net effect is to transfer hydrogen from kerogen to the bitumens (Barker, 1982). 

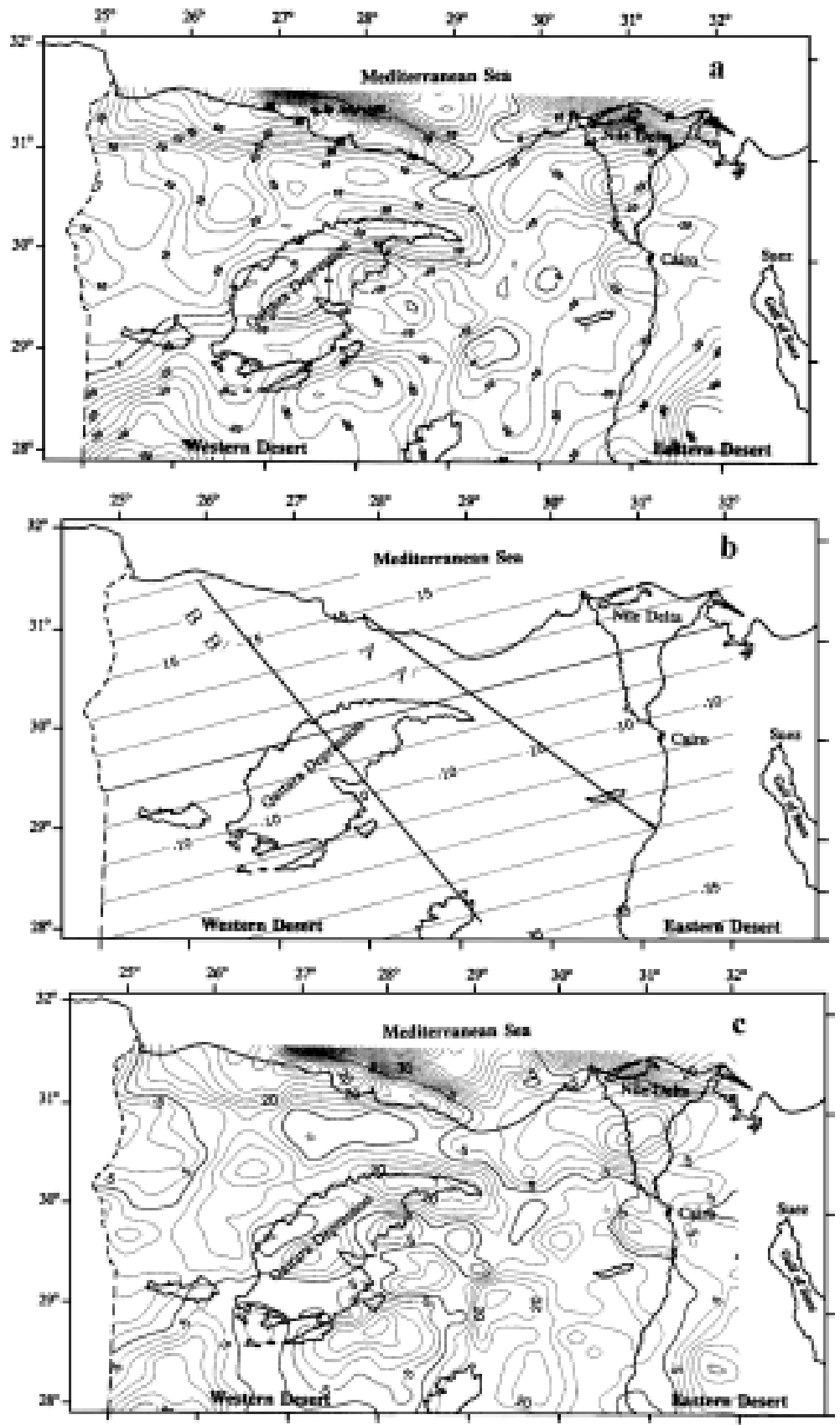

FIG. 3(a). Bouguer anomaly map of the northwestern desert (contour interval $5 \mathrm{mGal}$ ).

(b). Regional component of the Bouguer gravity map (c. i. 5 mGal).

(c). Residual component of the Bouguer anomaly map (c. i. $5 \mathrm{mGal}$ ). 

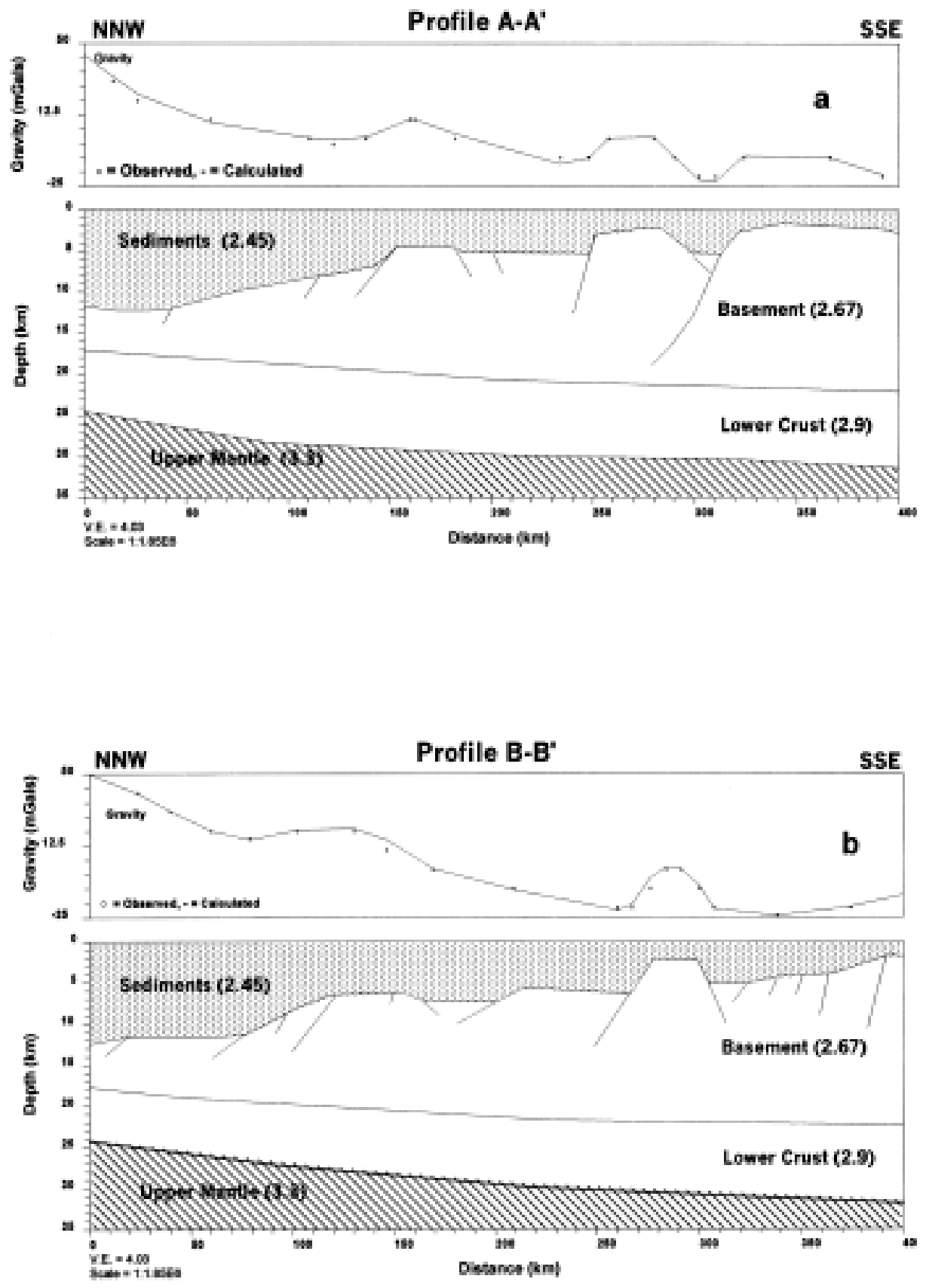

FIG. 4(a). 2D gravity modeling along profile AA'.

(b). 2D gravity modeling along profile $\mathrm{BB}^{\prime}$. 


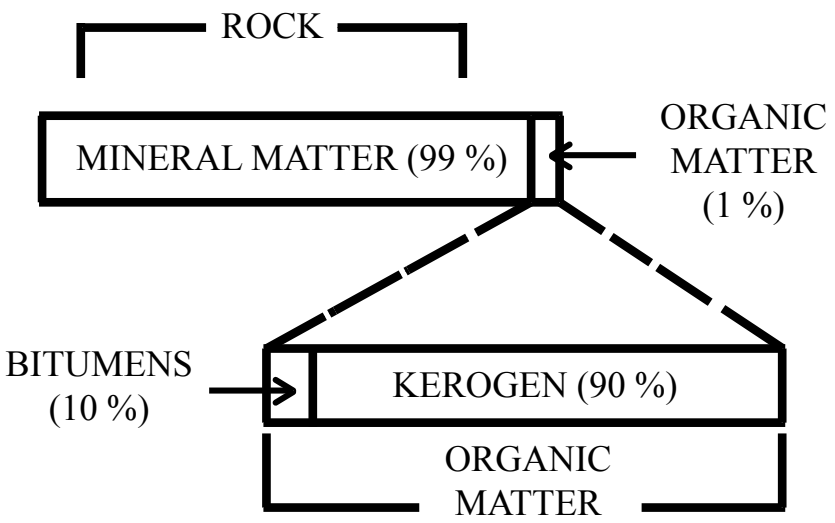

FIG. 5. Kerogen and bitumen in average shales (After Baker, 1982).

\section{Factors Controlling Diagenesis}

Temperature is the most important parameter in controlling the generation of petroleum. For each $10^{\circ} \mathrm{C}\left(18^{\circ} \mathrm{F}\right)$ rise in temperature, rate of reaction approximately doubles, so that although reaction rates are fairly slow near surface they increase rapidly with depth. This was demonstrated clearly by Philippi, (1965), in a classic study of Neogene sediments from the Los Angeles and Ventura basins of California. For rocks of different depths, he determined the amount of organic matter and the amount and composition of the solvent extractable bitumens in the $\mathrm{C}_{15+}$ range (Fig. 6). This shows that the generation of the extractable hydrocarbons is controlled by temperature. Pressure has only a minor role, if indeed it has a role at all.

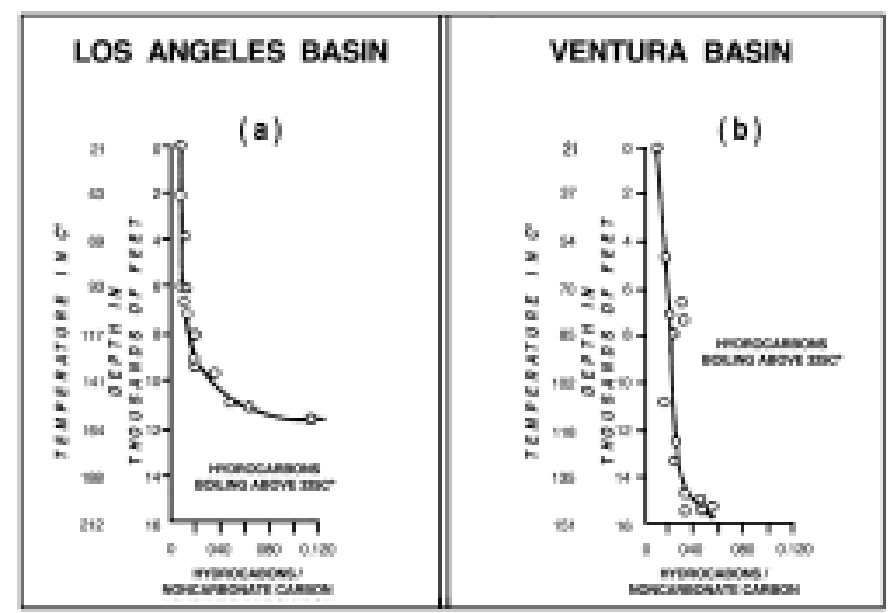

FIG. 6. Variation of the hydrocarbon/noncarbonate carbon ratio with depth and age in shales from the Los Angeles and Ventura Basins, California (After Philippi, 1965). 
The effect of temperature on organic matter is provided by laboratory heating experiments (Pyrolysis), which can duplicate many of the features observed for subsurface samples. In order to produce appreciable reaction in a reasonable length of time, the temperature must be higher than those encountered in the subsurface (Barker, 1982).

The effect of the generation process is summarized in Fig. 7, which shows that biologically derived molecules form an important part of the bitumens in shallow samples but become quantitatively less important in deeper samples. The bitumens start with strong biogenic characteristics and show marked oddcarbon preference in the normal paraffins, high abundances of 4- and 5- ring naphthenes and bimodal distribution of aromatics. Generation produces a more mature extract with a CPI (Carbon Preference Index) closer to one and a distribution of multirigid naphathenes and aromatics, which more closely approximate thermodynamics equilibrium. In the deepest sample the hydrocarbons becomes steadily lighter, giving at first wet gas and ultimately dry gas.

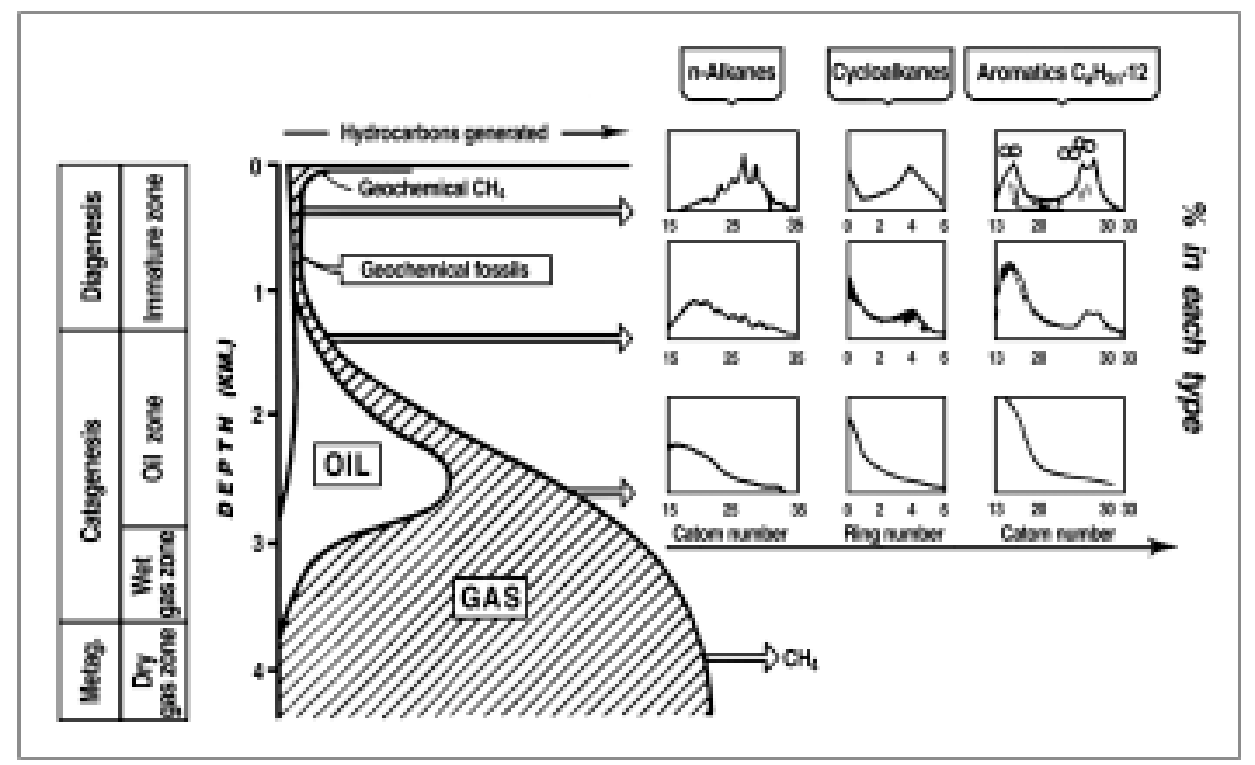

FIG. 7. General schematic of hydrocarbon formation as a function of burial of the source rock. The evolution of hydrocarbon composition is shown in insets for three different depths. The depth scale is only approximate and will depend on geothermal gradient. The values given correspond to an average for Mesozoic and Paleozoic source rocks. Actual depths will also depend on organic matter type and burial history (After Tissot et al., 1974). 
The time has a role in the diagnesis of organic matter, but it is secondary to that of temperature. Doubling the available time has the same effect as increasing the temperature by approximately $10^{\circ} \mathrm{C}$, so that the amount of products increases linearly with increasing time but exponentially for increasing temperature.

\section{Maturation of Petroleum}

The evolution of a crude oil involves a process of continuous, irreversible change, usually called "maturation", which leads from a heavy, immature" crude oil towards mature crudes which are lighter. This trend was recognized as early as 1915 that in areas where coal and oil occur (White, 1915) together, the higher rank coals were associated with oils of highest API Gravity (specific weight of oils adopted by the American Petroleum Institute). Since rank was known to increase with temperature it followed that API gravity also increased with temperature.

Temperature has a major role in maturation, and thermal cracking is the most important mechanism. Crude oils are not equilibrium mixtures and as temperature increases they readjust towards equilibrium at an increasing rate.

The trend from oil to gas with increasing temperature implies that there is some definite temperature above which oil will not be found. On the other hand it takes a certain amount of temperature for oil generation to begin so that oil is only available over a limited temperature range. Pusey (1973) has called this, the oil window. His figure (based on earlier work by Landes, 1967) and reproduced here as Fig. 8 shows how the depth of the oil window varies with geothermal gradient. Note that in areas with high geothermal gradient oil can be generated at shallower depths but the total oil reserves are in this case likely to be less because the depth interval between generation and destruction is smaller.

Pusey's representation is limited for application because it does not show the role of time. The temperature needed for the onset of petroleum generation is modified by the effects of geological age (as shown in Fig. 9) and this effect has been included in extending the oil window concept as shown in Fig. 10.

\section{Hydrocarbon Window in the Northwestern Desert}

Most of the published studies on similar subjects accept that the liquid hydrocarbon window could be present in the range of $90^{\circ} \mathrm{C}$ and $150^{\circ} \mathrm{C}(\operatorname{Riad}$ et al., 1989). In the Northwestern Desert, the depths at which these temperatures expected were calculated for each of the studied wells using equation 2 and the depth contour maps at which temperature $90^{\circ} \mathrm{C}$ and $150^{\circ} \mathrm{C}$ are reached, were constructed (Fig. 11 and 12). 


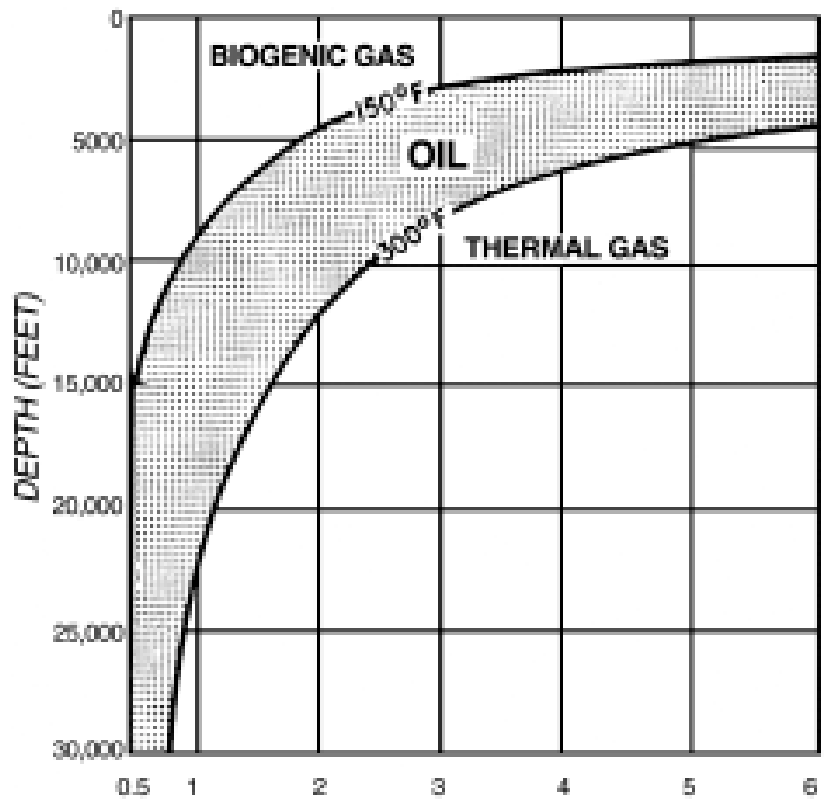

FIG. 8. Thermal gradient $\left({ }^{\circ} \mathrm{F} / 100 \mathrm{ft}\right)$.

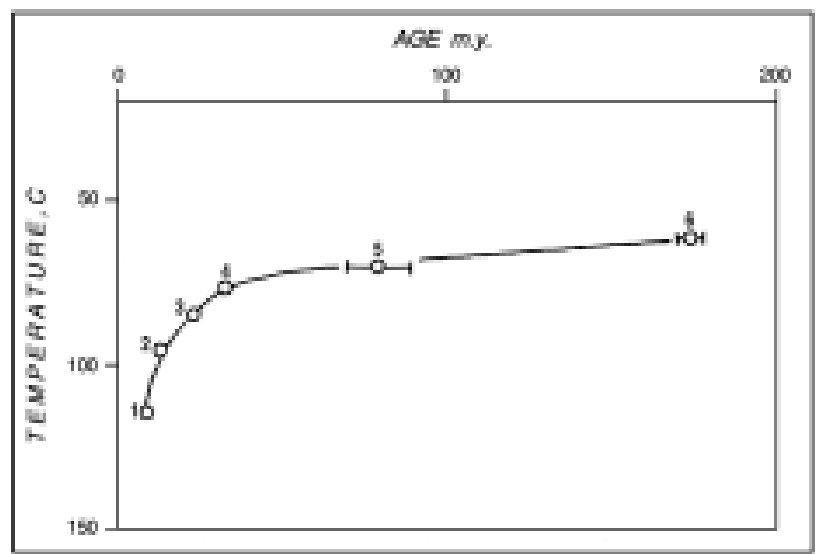

FIG. 9. Temperature required for the onset of petroleum generation in basins of different ages. Note that depth of generation is much more sensitive to depth of burial for Tertiary sequences (After Tissot et al., 1974). 


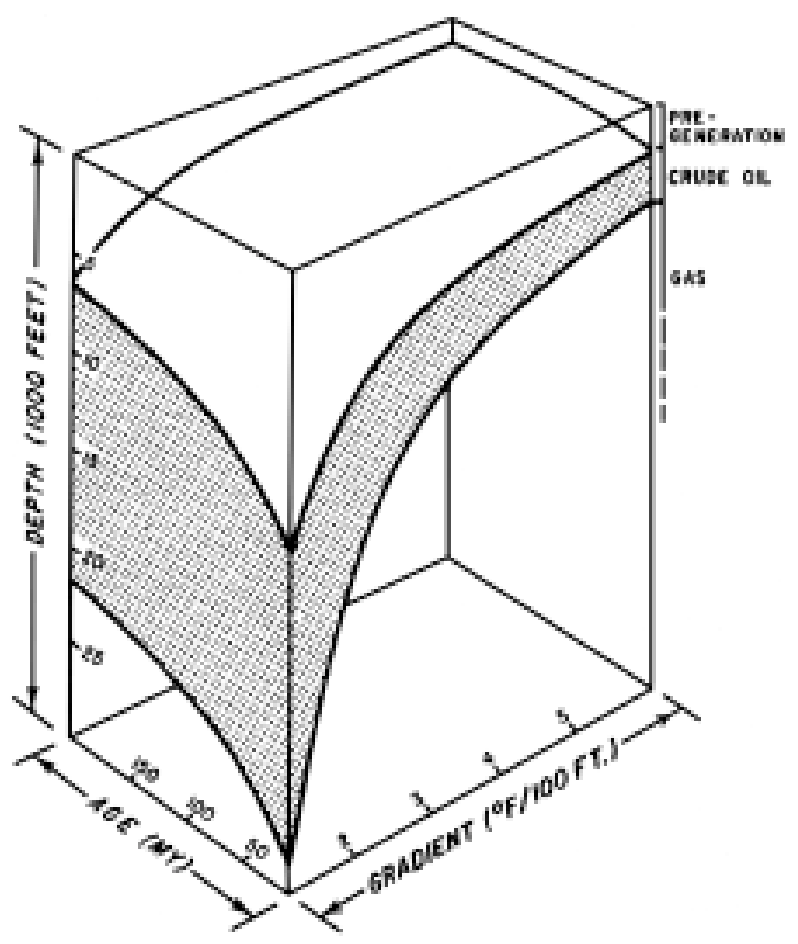

FIG. 10. The generation and destruction of crude oil related to depth, age and geothermal gradient. The top surface corresponds to oil generation and the bottom surface to destruction. Neither should be taken as sharp boundaries but rather as gradational changes (After Barker, 1982).

The Isopach map of the liquid hydrocarbon window in the Northwestern Desert (Fig. 13) shows areas where the hydrocarbon window is thick enough, reaching $3 \mathrm{~km}$ and including promising areas for oil exploration if the source rock is present. These areas include the southwestern part of the area under study. A comparison between the upper, lower limits and thickness of the oil window is given in Fig. 14. The isopach map for the hydrocarbon window was correlated with known sedimentary basins in the Paleozoic (Fig. 15) and the oil and gas fields (Fig. 16). Fairly good correlation was found especially for thickness of hydrocarbon window values $>2 \mathrm{~km}$ with the distribution of these basins (e.g. Abu-Ghardig basin and Alamein field).

\section{Geothermal Trend Analysis}

Egypt is affected by the structural elements and tectonics of the northeastern corner of the African plate and the south east of the Mediterranean Sea (Neev, 1977; Ginzburg and Gvirtzman, 1979; Orwig, 1982; Neev et al., 1985; Ben Avraham et al., 1987; Harms and Wray, 1990; Zeyen, 1997) and by the tectonic of 


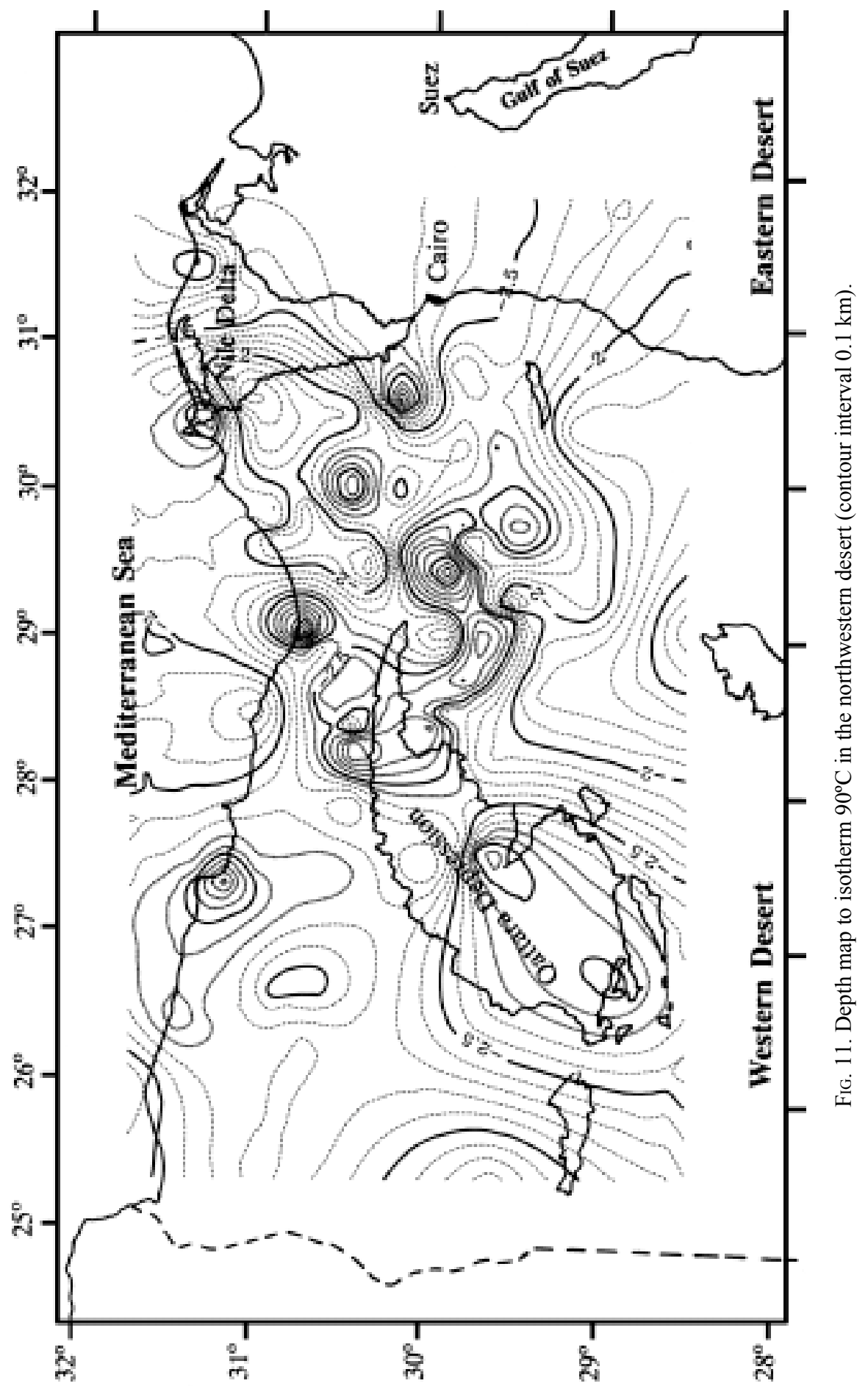




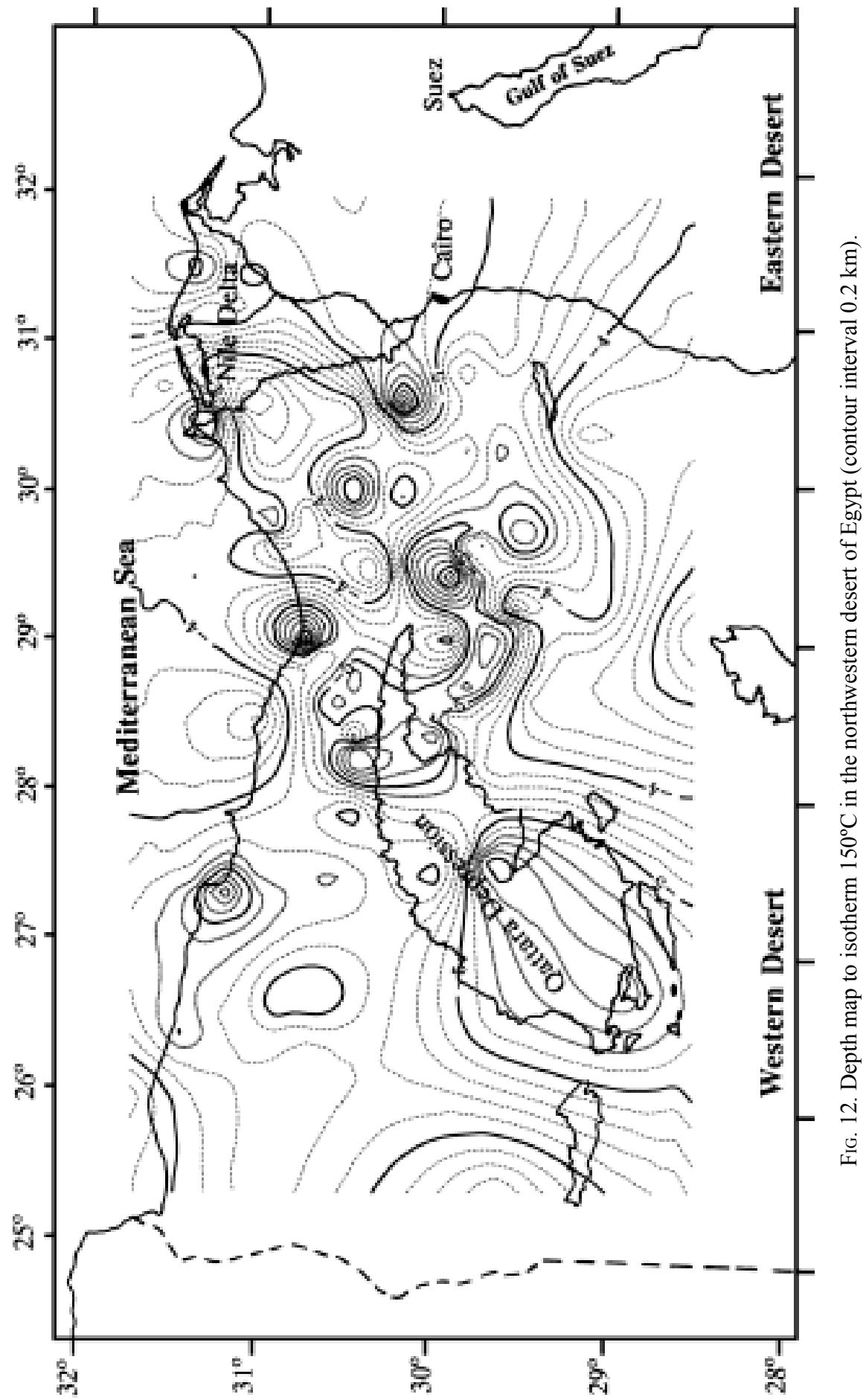




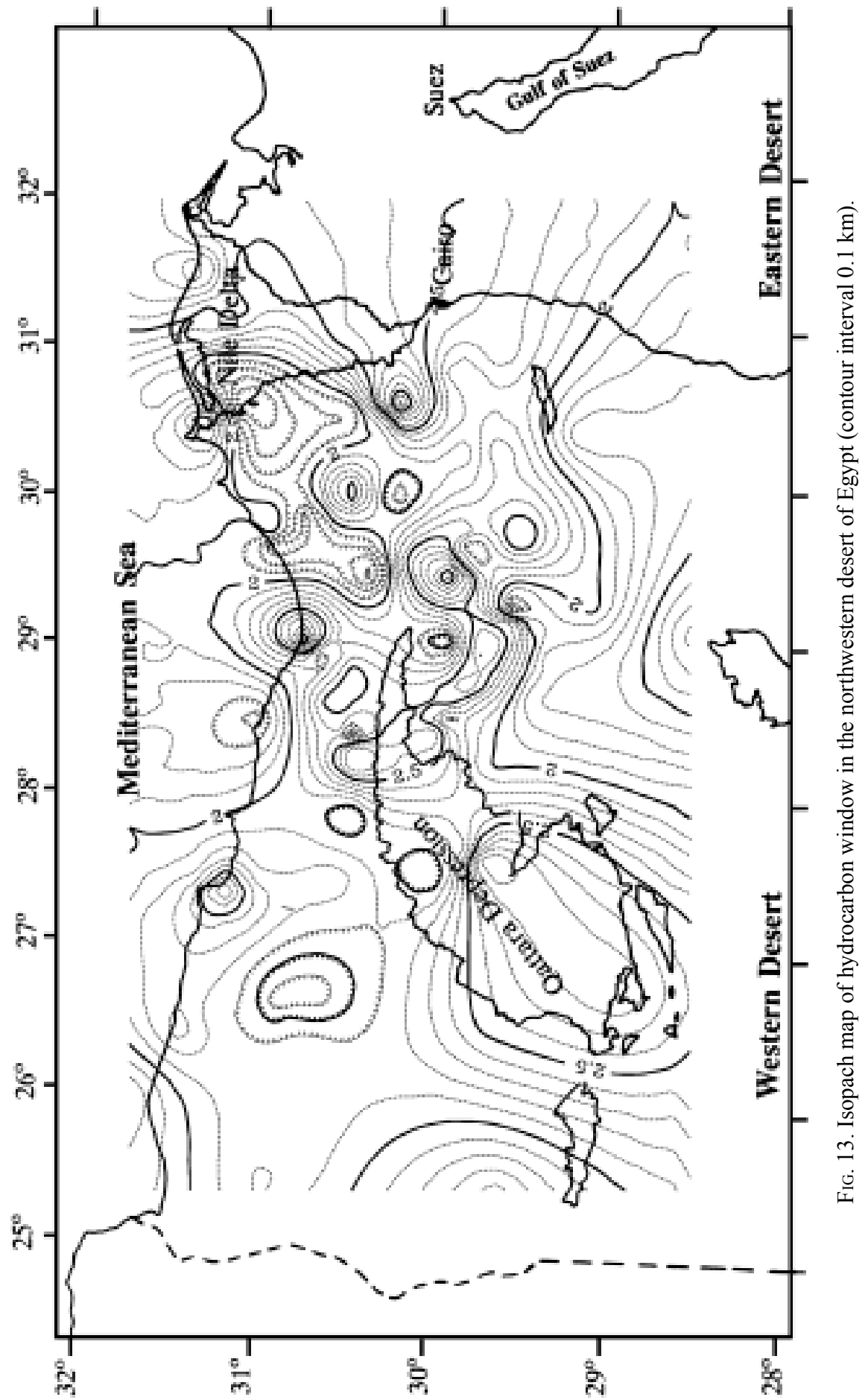




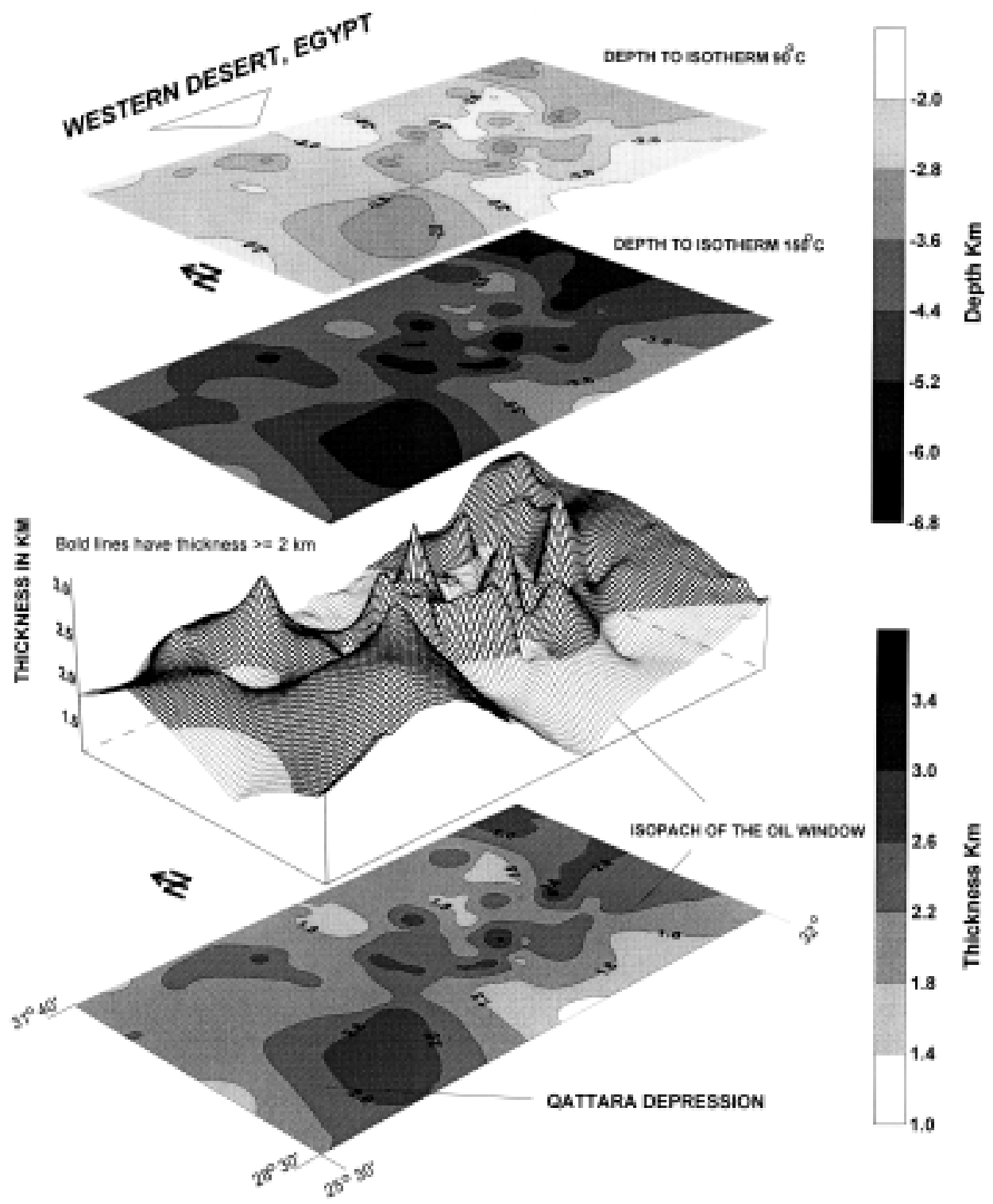

FIG. 14. The upper, lower limits and the thickness of the oil window. 


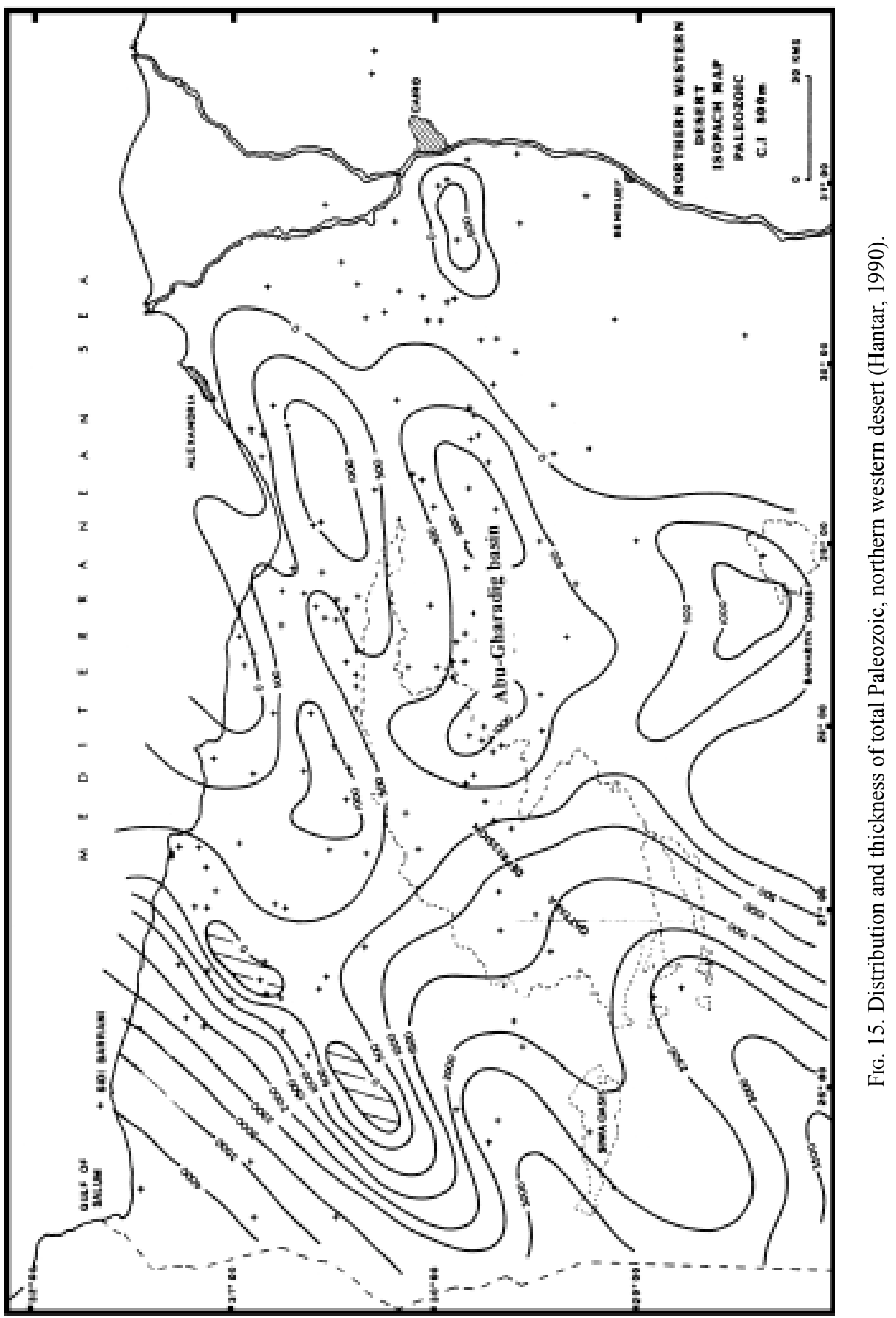




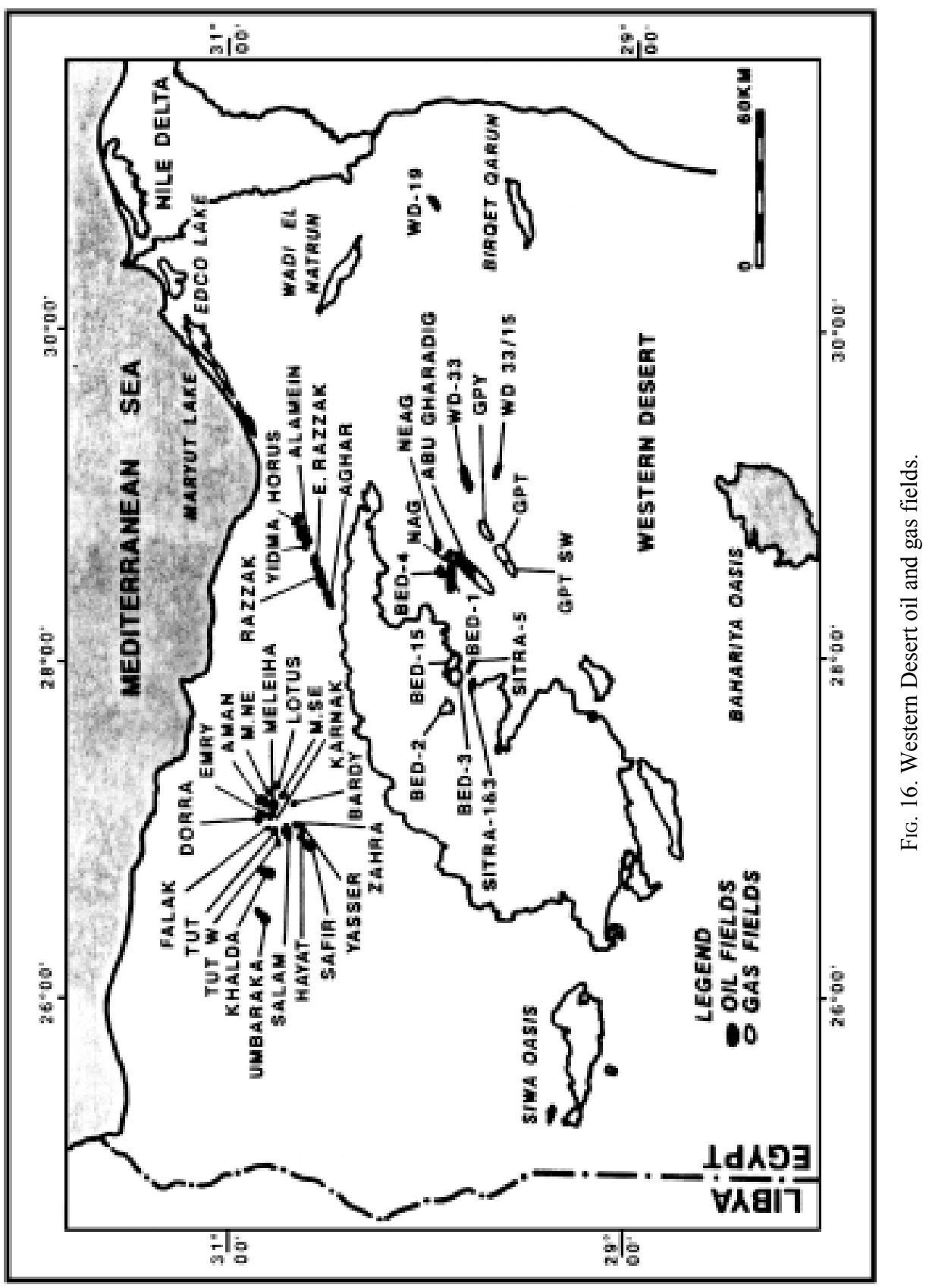


Sinai subplate and the Gulf of Suez-Red Sea Rift System (Stanley and Goodfriend 1997, Meshref, 1999). Some authors (Morgan et al., 1980; 1983; 1985; Swanberg et al., 1983; Boulus, 1990; Hosney and Dahroug 1999; Hosney and Morgan 2000; Hosney 2001 and 2002) found a strong correlation among geothermal anomaly and the basement surface in the northern Egypt and the Gulf of Suez.

To investigate whether the geothermal gradient is affected by the basement structures, geothermal trend analysis has been carried out by locating zones of high gradient strips on the geothermal gradient map (Fig. 17a). Geothermal trend analysis reveals the presence of the following main trends (Fig. 17b): N45 $-65^{\circ} \mathrm{E}$ (Syrian arc, Pelusium and Siwa-Alexandria), N25 ${ }^{\circ} \mathrm{W}$ (Red Sea and Gulf of Suez) and $\mathrm{N} 80^{\circ} \mathrm{E}$ (Tethyan Sea). These lineaments appear to be caused primarily by basement structures and overlying sediments, since they are considered as major structural trends characterizing the basement of Egypt. They affect the hydrocarbon oil window of the area.

\section{Conclusions}

1 - The geothermal gradient values in the Northwestern Desert range between $19.8^{\circ} \mathrm{C} / \mathrm{km}$ and $51.7^{\circ} \mathrm{C} / \mathrm{km}$. The highest values are located in the southern central part south of latitude $29^{\circ} \mathrm{N}$. Heat flow values over the studied area were found to range between $43-110 \mathrm{mWm}^{-2}$, assuming that the thermal conductivity values for the rocks forming the stratigraphic section in northern Egypt to range between $2-2.3 \mathrm{w} / \mathrm{m}^{\circ} \mathrm{C}$.

2 - There is a regional decrease in geothermal gradient values northward, which may be due to thinning of the radioactive isotopes rich continental crust toward the Mediterranean Sea. This trend apparently correlates with decrease in crustal thickness from about $33 \mathrm{~km}$ at the southern part of the studied area, to 24 $\mathrm{km}$ beneath the Mediterranean coast.

3 - Geothermal trend analysis reveals the presence of the following main trends: N45-65E (Syrian arc, Pelusium and Siwa-Alexandria), N25W (Red Sea and Gulf of Suez) and N80E (Tethyan Sea). These lineaments appear to be caused primarily by basement structures and overlying sediments. They affect the hydrocarbon oil window of the area. The high geothermal gradients are associated with shallow basement depths.

4 - Maps representing the depth of the isotherms of the upper and lower limit of the hydrocarbon window and the isopach map were correlated with known sedimentary basins in the Paleozoic and oil and gas fields. Fairly good correlation was found especially for thickness of hydrocarbon window of values $>2 \mathrm{~km}$ with the distribution of these basins and the oil fields. 

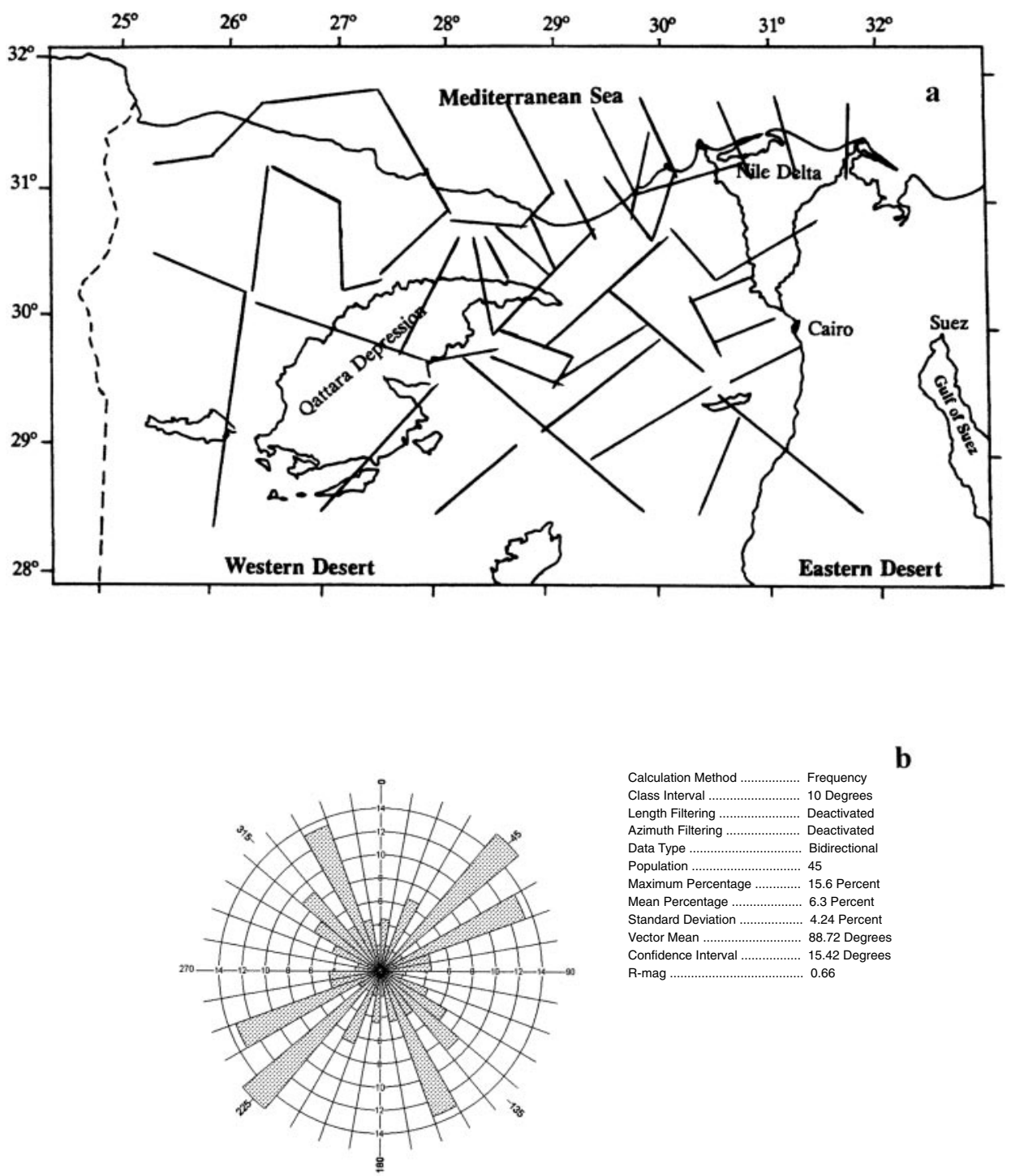

b

FIG. 17(a). Location of the geothermal trends, north western desert.

(b). Frequency $\%$ of the geothermal trends. 
5 - Parts of the study area which are not explored yet but show thick hydrocarbon window $(2.5-3 \mathrm{~km})$ is considered target areas for future exploration programs. Among these parts is the area south to south west Qattara depression and Abu-Gharadig basin.

\section{References}

Barker, C. (1982) Petroleum generation and occurrence for exploration geologist, Oil and Gas Consultants International, Inc., Tulsa Oklahoma, U.S.A.

Beck, A.E. and Balling, N. (1988) Determination of virgin rock temperatures, in: R. Haenel, L. Rybach and L. Stegena (ed.), Handbook of Terrestrial Heat-Flow Density Determination, Kluwer Academic Publishers, pp: 59-85.

Ben Avraham, Z., Nur, A. and Cells, G. (1987) Active transcurrent fault system along the North African passive margin, Tectonophysics, 141: 254-260.

Boulos, F.K. (1990) Some aspects of the geophysical regime of Egypt in relation to heat flow, groundwater and microearthquakes, in: R. Said (ed.), The Geology of Egypt, A.A. Balkema, Rotterdam, pp: 61-89.

Čermak, V. and Hurtig, E. (1977) Preliminary Heat Flow Map of Europe 1:5000000, IASPEI Heat Flow Commission, Potsdam, GDR.

Dowdle, W.L. and Cobb, W.M. (1975) Static formation temperature from well logs - an empirical method, J. Petrol. Technol., 27: 1326-1330.

Eckstein, J. (1979) Heat flow and the hydrological cycle, examples from Israel, in: V. Cermak and L. Rybach (ed.), Terrestrial Heat Flow in Europe, Springer-Verlag, Berlin, pp. 88-97.

Eckstein, Y. (1978) Review of heat flow data from the Eastern Mediterranean region, Pageoph, 117, Bir Khauser Verlag, Basel.

Ginzburg, A. and Gvirtzman, G. (1979) Changes in the crust and upper mantle across the transition from Arabian Platform to the Mediterranean basin, evidences from seismic refraction and sedimentary studies in Israel and Syria, Journal of Sedimentary Geology, 23: 19-38.

Hantar, G. (1990) North Western Desert, in: R. Said (ed.), The Geology of Egypt, A.A. Balkema, Rotterdam, pp: 293-319.

Harms, J.C. and Wray, J.L. (1990) Nile Delta, in: R. Said (ed.), The Geology of Egypt, A.A. Balkema, Rotterdam, pp: 329-343.

Horner, R.D. (1951) Pressure build-up in wells, Proc. Third World Petroleum Congress, The Hague, 34: 316.

Hosney, H. (2001) An introduction to the geothermal regime and its tectonic implications of the Suez Rift System, Journal of Environmental Sciences, 22: 157-182. The Univ. of Mansoura, Egypt. Mansoura, Egypt.

Hosney, H. (2002) Geophysical parameters and crustal temperatures characterizing tectonic and heat flow provinces of Egypt, Al-Azhar Bull. Sci., 13(2) (Dec.): 111-126.

Hosney, H. and Dahroug, S.M. (1999) Nile Delta geothermal data from oil wells, Mans. Sci. Bull. (C Nat. Sci. and Phys. Sci.), 26(1): 49-66.

Hosney, H. and Morgan, P. (2000) Geothermal behavior and tectonic setting in the Northern Gulf of Suez, Egypt, Journal of Environmental Sciences, 19: 55-74.

Hunt, J.M. (1972) Distribution of Carbon in Crust of Earth, Bull. AAPG, 56: 2273-2277.

Issar, A., Rosenthal, E., Eckstein, Y. and Bogoch, R. (1971) Formation waters, hot springs and mineralization phenomena along the eastern shore of the Gulf of Suez, Bull. Int. Assoc. Sci. Hydrology, 16: 25-44. 
Kamel, H. (1990) Gravity map of Egypt, in: R. Said (ed.), The Geology of Egypt, A.A. Balkema, Rotterdam, 48-49.

Lachenbruch, A.H. and Brewer, M.C. (1959) Dissipation of the temperature effect of drilling a well in Arctic Alaska, U.S. Geol. Surv. Bull., 1083-C: 73-109.

Landes, K.K. (1967) Eometamorphism, and oil and gas in time and space, Bull. AAPG, 51: 828841.

Luheshi, M.N. (1983) Estimation of formation temperatures from borehole measurements, Geophys. J., Roy Aston. Soc., 74: 747-776.

Makris, J., Weigel, W., Moeller, L., Goldform. P., Behle, A., Stoefen, B., Allam, A., Maamoun, M., Delibasis, N., Perissoratis, K., Avedik, F. and Giese, P. (1982) Deep Seismic Soundings in Egypt, Part 1: The Mediterranean Sea between Crete-Sidi Barrani and the Coastal Aareas of Egypt, Internal report, University of Hamburg, FRG.

Marzouk, I. (1988) Study of the Crustal Structure of Egypt, Deduced from Deep Seismic and Gravity Data., Ph.D. Thesis, Univ. of Hamburg, Hamburg, F.R. Germany.

Meshref, W.M. (1999) Cretaceous tectonics and its impact on oil exploration in northern Egypt, Geological Society of Egypt, Special Publication (2): 199-244.

Middleton, M.F. (1979) A model for bottom-hole temperature stabilization, Geophysics, 44: 1458-1462.

Morgan, P., Blackwell, D.D., Farris, J.C., Boulos, F.K. and Salib, P.G. (1977) Preliminary geothermal gradient and heat flow values for northern Egypt and the Gulf of Suez from oil well data, in: Proceedings, Int. Cong. Thermal Waters, Geothermal Energy and Volcanism of the Mediterranean Area, Nat. Tech. Univ., Athens, Greece, 1: 424-438.

Morgan, P., Boulos, F.K. and Swanberg, C.A. (1983) Regional geothermal exploration in Egypt, Geophysical Prospecting, 31: 361-376.

Morgan, P., Boulos, F. K., Hennin, S.F., EI-Sherif, A.A., El-Sayed, A.A., Basta, N.Z. and Melek, Y.S. (1985) Heat flow in Eastern Egypt: The thermal signature of a continental breakup, J. Geody., 4: 107-131.

Morgan, P., Swanberg, C.A., Boulos, F.K., Hennin, S.F., El-Sayed, A.A. and Basta, N.Z. (1980) Geothermal studies in northeast Africa, Annals Geol. Surv. Egypt, 10: 971-987.

Nafe, J.E. and Drake, C.L. (1963) Physical properties of marine sediments, In: Hill, M.N. (ed.), The Sea, Vol. 3, Interscience, New York.

Neev, D. (1977) The Pelusium line, a major transcontinental shear, Tectonophysics, 38: T1-T8.

Neev, D., Greenfild, L. and Hall, J.K. (1985) Slice tectonic in the eastern Mediterranean basin, in: D.J. Stanley and F.C. Wezel, (ed.), Geological Evolution of the Mediterranean Basin. Springer Verlag, New York, pp: 249-269.

Orwig, E.R. (1982) Tectonic framework of northern Egypt and the eastern Mediterranean region, $6^{\text {th }}$ Exploration Seminar. The Egyptian General Petroleum Corporation, Cairo.

Philipi, G.T. (1965) On the depth, time and mechanism of petroleum generation, Geochim. Cosmochim. Acta, 22: 1021-1040.

Pusey, W.C. (1973) How to evaluate potential gas and oil source rocks, World Oil, April 1973, 71-75.

Riad, S., Abdelrahman, E.M., Refai, E. and El-Ghalban, H.M. (1989) Geothermal studies in the Nile Delta, Egypt. J. of Afr. Earth Sciences, 9(3/4): 637-649.

Ribeiro, F.B. and Hamza, V.M. (1986) Stabilization of bottom holes temperature in the presence of formation fluid flows, Geophysics, 51: 410-413.

Schlumberger (1984) Well Evaluation Conference of Egypt, Schlumberger Middle East. S.A.

Schlumberger (1995) Well Evaluation Conference of Egypt, Schlumberger Technical Editing Services, Chester. 
Shen, P.Y. and Beck A.E. (1986) Stabilization of bottom hole temperature with circulation time and fluid flow, Geophys. J. Roy Aston. Soc., 86: 63-90.

Stanley, D.J. and Goodfriend, G.A. (1997) Recent subsidence of the northern Suez Canal, Nature, 388: 335-336.

Swanberg, C.A., Morgan, P. and Boulos, F. (1983) Geothermal potential of Egypt, Tectonophysics, 96: 77-94.

Tissot, B., Durand, B., Espitalie, J. and Combaz, A. (1974) Influence of nature and diagenesis of organic matter in formation of petroleum, American Association of Petroleum Geologists Bulletin, 58(3): 499-506.

White, D. (1915) Some relations in origin between coal and petroleum, J. Wash. Acad. SCL., V.S.: $189-212$.

Zaghloul, Z.M., Shaaban F.F. and Yousef, A.F. (1995) Subsurface Quaternary geothermal reservoir in the Nile Delta area, Journal of Environmental Sciences, 9: 187-204.

Zeyen, H., Volker, F., Wehrle, V., Fuchs, K., Sobolev, S. and Altherr, R. (1997) Styles of continental rifting crust-mantle detachment and mantle plumes, Tectonophysics, 278: 329-352. 


\title{
تحقيقات جيوحرارية واحتمالات الهيدروكربونات فى شمال الصحر اء الغربية
}

\author{
حسن محمد حسن حسني \\ قسم الجيوفيزياء ، كلية العلوم ، جامعة القاهرة \\ القاهـــــرة - مصر العاء
}

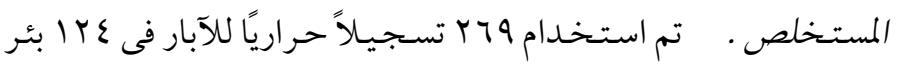

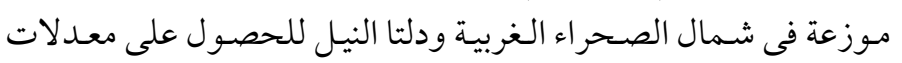

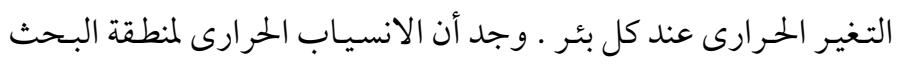

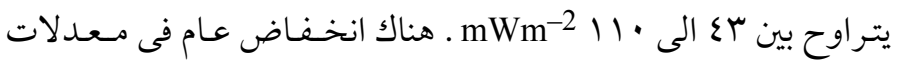

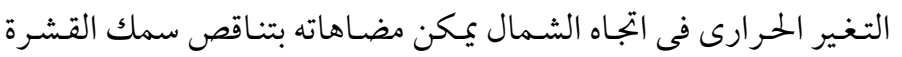

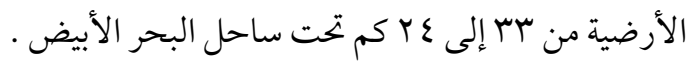

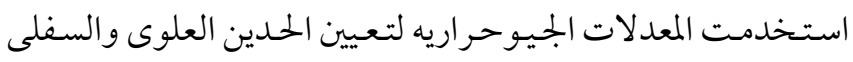

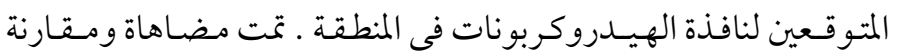

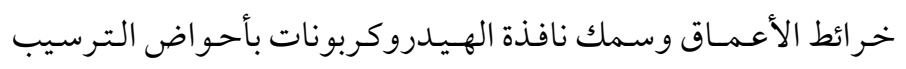

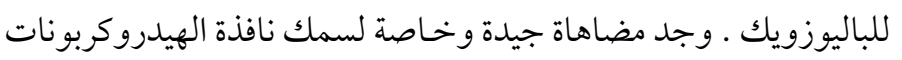

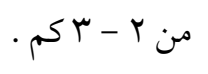

تحليل اتجاه معدلات التغير الجيوحرارى أظهر وجود اتجاهات رئيسة

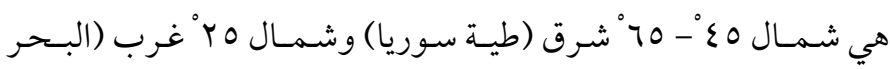

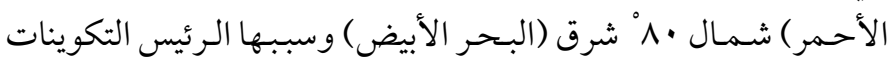

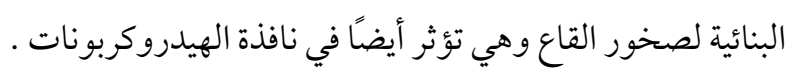

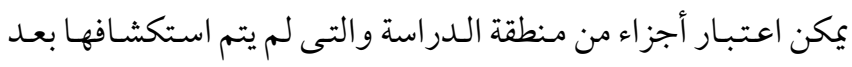

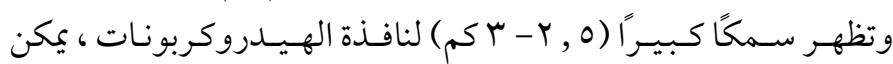

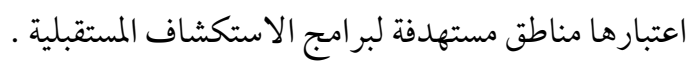

